\title{
INTERNATIONAL INVESTMENT LAW AND THE RIGHT TO HEALTH
}

\author{
DERECHO INTERNACIONAL DE INVERSIONES \\ $Y$ EL DERECHO A LA SALUD
}

\section{Catalina Sofía Rizo Massu*}

\begin{abstract}
This article reflects on the hurdles of the right to health within international investment dispute settlement. Its main purpose is to analyze the way in which both, the right to health and property rights should fit there. In doing so, relevant jurisprudence, normative and pragmatic arguments are provided. Some of the measures and strategies proposed so far to foster cohabitation between both branches of international law are challenged in an attempt to demonstrate that none of them will effectively contribute to better protect the right to health. Likewise, it offers less explored solutions, such as engaging the World Health Organization and the International Court of Justice, and a shift in the onus of proof through the application of the Precautionary Principle.
\end{abstract}

Key words: International Court of Justice, Investor-State Dispute Settlement, Precautionary Principle, Right to Health, World Health Organization.

RESUMEN: Este artículo aborda los obstáculos que enfrenta el derecho a la salud en el sistema internacional de resolución de controversias de inversiones extranjeras. Analiza jurisprudencia relevante, argumentos normativos y pragmáticos y pretende que, tanto la protección al derecho a la salud como a la propiedad, tengan cabida. Desafía las actuales estrategias propuestas para fomentar la convivencia de ambos derechos, demostrando que ninguna de ellas contribuirá de manera efectiva a mejorar la protección del derecho a la salud. Asimismo, explora nuevas medidas para enfrentar el problema, como la incorporación de la Organización Mundial de la Salud y la Corte Internacional de Justicia, y la alteración en la carga de la prueba mediante la aplicación del principio de precaución.

Palabras clave: Corte Internacional de Justicia, Sistema Internacional de Resolución de Controversias de Inversiones Extranjeras, Principio de Precaución, Derecho a la Salud, Organización Mundial de la Salud.

\section{INTRODUCTION}

Challenges faced by the interplay between international investment law (IIL) and other international regimes have become evident at a fast speed ${ }^{1}$. Central to the debate are those concerns on how to adapt regulatory powers of the state to a variety of crises around

\footnotetext{
* Master of International Law from University College London (UCL).Chief of the Women and Work Area at the National Service for Women in Chile. Postal address: Capullo 2245, Providencia, Chile. E-mail: c.rizo. massu@gmail.com.

1 ЈАСОВ (2010) p. 31.
} 
the world ${ }^{2}$ and their permeation in the field of investment law ${ }^{3}$. Furthermore, when assessing costs and benefits of investment protection treaties, it is frequently argued that the impact on governments vary from a "regulatory chill" to a loss of their right to regulate ${ }^{4}$ as their autonomy to develop and implement policy is constrained".

Possible clashes between IIL and international health law (IHL) are particularly interesting for two reasons; (1) sensitive matters that are at stake and decisions taken on them have far-reaching implications for the well-being of millions of people $e^{6}$; and (2) the way in which international law has evolved in both fields. Traditionally, IIL is predominantly a creature of treaties and customs $s^{7}$ and so far its main aim has been to shape a stable legal framework for foreign investment ${ }^{8}$. Conversely, health affairs have become a globalized challenge ${ }^{9}$, encompassing a variety of complex concerns which are hard to tackle without international cooperation ${ }^{10}$. In this regards, IHL has evolved from a minimalist position focused solely on health care ${ }^{11}$ and a narrow preventive approach on cross-border infectious disease control ${ }^{12}$ towards a more inclusive one that aims to tackle non-communicable diseases (NCDs) and improve the health of individuals ${ }^{13}$. However, what has been more critical from the interplay perspective, is the shift in the regulatory strategy from a prohibitionist system ${ }^{14}$ to a strict regulatory market ${ }^{15}$ where certain substances "sit in a regulatory no man's land" and "are neither completely regulated as licit products nor treated as illicit ones" ${ }^{\prime 6}$. This specific type of framework regulation is more likely to collide with vested rights within IIL, broadening the sphere of conflict among both regimes ${ }^{17}$.

To understand the scenario in which these interests come into play, the first section of this essay situates the framework of health and property rights in international law. The second section outlines some of the key issues within IIL that are likely to undermine an adequate level of protection of the right to health. The purpose of both is to demonstrate the hurdles of the right to health when a dispute between states and foreign investors arise. 
The final section, examines some less explored solutions as alternatives to enlighten the debate with the aim of contributing to a more balanced system.

\section{PUBLIC INTERNATIONAL LAW: THE OUTER SETTING}

This section frames the general landscape within which these two rights come into play to set the outer rules of the game, focusing on the variety of commitments in the international agenda and their asymmetric structure.

\subsection{The INTERNATIONAL AGENDA}

Different branches of international law have evolved separately due to contextual and ideological dissimilarities ${ }^{18}$. One view of fragmentation is to rely on the presumption of lawfulness within the different regimes ${ }^{19}$, namely that "investment law and human rights are two fields of international law pursuing the same powerful project of a global rule of law" ${ }^{20}$. Indeed, health and private property are both human rights and matters of public interest ${ }^{21}$. As such, both deserve a sufficient degree of protection. Another perspective is that different fields focus on differing aspects ${ }^{22}$, thus increasing tension between the varieties of commitments that governments acquire ${ }^{23}$.

In recent years, it has been frequently argued that property rights have expanded "too far, at the expense of the public weal" 24 . To illustrate, the cases challenging tobacco control measures that were brought against Uruguay and Australia were grounded on the argument that regulations issued by the host states to comply with the World Health Organisation (WHO) Framework Convention on Tobacco Control (FCTC) violated international investment agreements (IIAs) ${ }^{25}$. Despite an assessment of specific state measures, the FCTC encouraged states to introduce regulations that went beyond its requirements ${ }^{26}$, even if colliding with economic interests of the related industry ${ }^{27}$. Indeed, this exemplifies the incoherence and inconsistency between these regimes.

Within the broader international setting there is little difference. The Sustainable Development Goals (SDGs) and article 12 of the International Covenant on Economic, Social and Cultural Rights (ICESCR), both embrace a broad scope of the right to health and encompass comprehensive policy directions in which both preventive and ex post actions are expected to be taken ${ }^{28}$.

\footnotetext{
18 Alvarez (2016).

19 BetTCHer et al. (2000) p. 195.

20 ЈАСОВ (2010) p. 3.

21 Desierto (2015) p. 37.

22 Alvarez (2016).

23 Dumberry and Dumas-Aubin (2014) p. 569.

24 VADI (2009) pp. 773, 774.

25 ZHAN (2013) p. 23.

26 See Art 2(1) of the WHO FCTC.

27 Zhan (2013) p. 24. See Art. 5.3 of the WHO FCTC.

28 WHO, Sustainable Development Goals (SDGs).
} 
Whichever option one holds, it is a fact that governments acquire commitments with other states or non-state actors and, as a consequence, voluntarily raise the cost of violations to these commitments ${ }^{29}$. The 2001 International Law Commission's articles on Responsibility of States for Internationally Wrongful Acts (ILC), indicates that non-compliance of specific obligations create secondary obligations for the states ${ }^{30}$. Thus, attribution and breach are enough to incur in an internationally wrongful act ${ }^{31}$. It is not accepted that a state's non-compliance is justified in other international obligations ${ }^{32}$. The state may try to rely on the breach of international obligations of an investor's home state to allege that the host state's policy measure was adopted as "a countermeasure in response to an anterior breach by a home state" 33 . In this case, the argument would be grounded in the previous violation of the duty of the investor's home state to ensure that their nationals do not act in ways that cause violations of the state's fundamental obligations to "respect," "protect," and "fulfill" ICESCR rights ${ }^{34}$. However, invoking the ICESCR independently of the IIA would only be an available option where the state is a party to both the IIA and the ICESCR ${ }^{35}$ and even the latter is not a uniform interpretation ${ }^{36}$.

Also, countermeasures are a valid means to be taken against other states but not against investors ${ }^{37}$. ILC article 50 (1) (b) is clear when setting forth that "[c]ountermeasures shall not affect: (b) obligations for the protection of fundamental human rights", so their effect will ultimately depend on the nature of the investors' rights ${ }^{38}$. In any case, according to ILC article 27, compensation for material losses would still be due. Thus, even if the foreign investor's home state waived responsibility, such action would impact more on the amount of compensation due rather than on any possible exemption to what is likely to be owed.

Another possible path for the host state could be to seek refuge in the consent of the investor's home state as a causative circumstance precluding wrongfulness for the breach of an investment treaty ${ }^{39}$. This implies having the home state of the investor consenting to the policy measure taken by the host state to safeguard health rights. Consent, however, is unlikely to be successfully opposable to the investor as a third party ${ }^{40}$. 
In this context, balancing trade-offs between the pursuit for economic interests and the promotion of public health, frequently involves dramatic choices ${ }^{41}$. Professor Vadi has suggested applying a similar solution to the one given in the 2003 UNESCO Convention for the Safeguarding of Intangible Cultural Heritage ${ }^{42}$. Thus, to ensure an appropriate counterbalance between intangible property rights and the right to health in IIL, the proposed plan would be to safeguard only those rights that are "compatible with existing human rights instruments" ${ }^{\prime 3}$. Other solutions stress the drafting of treaty exceptions ${ }^{44}$, conflict clauses ${ }^{45}$ and even exclusions of specific sectors from the scope of treaty protection ${ }^{46}$.

In my view, opting for a blanket choice for all future cases is unlikely to be consistent with a proper assessment of the specific circumstances of the case and might, therefore, turn into partial or short-time solutions. After all, threats to the right to health can come from a variety of industries that may not even be envisaged today or when subscribing to a given investment treaty. A sensible view of the issue will allow an adequate study of the legal and factual circumstances surrounding the dispute at stake without weakening the right to health and without allowing health issues to be used as an excuse to illegitimately undermine investor's protection either ${ }^{47}$. In short, a more balanced approach is needed where the question of the place of other regimes within investment law is as important as the question about the place of investment law within other international system $s^{48}$.

\subsection{VESTED RIGHTS, SOFT LAW AND POLICY}

Whilst taking into account that a flexible option is a preferred approach for these assessments, extreme flexibility is hardly sufficient to adequately protect health rights. Indeed, a deep asymmetrical relationship between health and property rights has been highlighted as the basis of an uneven playing field that ultimately undermines health protection ${ }^{49}$.

As a first dimension, one can point out the difference between dealing with binding and non-binding commitments. It is thought that many global health concerns are better tackled through policy than through justiciable rights ${ }^{50}$. Thus, save for a few exceptions $s^{51}$, the IHL path has been to advance in a variety of policy initiatives through UN agencies and other international organisations. The result has been to directly involve corporate investors via codes of conduct setting forth their duties. However, such codes are not

\footnotetext{
41 Wu (2010) p. 141.

42 See Art. 3.

43 VADI (2009) p. 788.

44 European Federation for Investment LaW and Arbitration [EFILA].

45 VADI (2009) p. 801.

46 ZHAN (2013) p. 26.

47 EFILA.

48 DiepeveEn et al. (2014) p. 147.

49 Dumberry and Dumas-Aubin (2014) p. 569.

50 Widdows (2015) pp. 391 and 397; Ferraz (2011) p. 1643; Pieterse (2008) p. 364.

51 Ruger (2008) pp. 434-435.
} 
binding $^{52}$, making it hard to integrate them with the obligations of states ${ }^{53}$. Ergo, while investors are often adequately protected by IIAs ${ }^{54}$, no specific obligations ${ }^{55}$ are directly imposed on them ${ }^{56}$ (except for jus cogens norms for which corporations can be held directly accountable $)^{57}$.

Additionally, in IIAs, counterpart duties imposed on the investor's home state are not found either ${ }^{58}$. Through treaties host states voluntarily risk their ability to either "pursue preferred policies"59 or to respond to their citizens' demands $s^{60}$. They tie their hands in the understanding that they will get the "development contribution they seek from foreign investment in return" ${ }^{61}$. Hence, the question that should immediately arise is which kind of development are states seeking for ${ }^{62}$. With a concept of development evolving from an economic approach to a human-centered one ${ }^{63}$ the question has no univocal answer. On one hand, development can broadly encompass an individual's potential through enlarging their choices and increasing their well-being ${ }^{64}$, which is in line with article 28 of the Universal Declaration of Human Rights (UDHR) that establishes what to expect from a human right and the goals set in the international agenda ${ }^{65}$. On the other hand, if a right cannot be matched with binding and specific duties ${ }^{66}$, it is somewhat unclear to what extent a non-state party can actually be subject to human rights obligations ${ }^{67}$. The difficulty of this situation can be envisaged in the decision-making process of a dispute. When arbitrators render an award, there is a high probability that they will face, on the one hand, vested rights and binding law and, on the other, mere policy implementation. Even where measures are focused on protecting the right to health, vested rights will inevitably have more weight than recommendations, self-regulation or policy choices ${ }^{68}$.

As a second dimension of this imbalance, IIL has been conceived as a one-sided regime ${ }^{69}$. Host states cannot request for arbitration since "this is a preserve of investors"

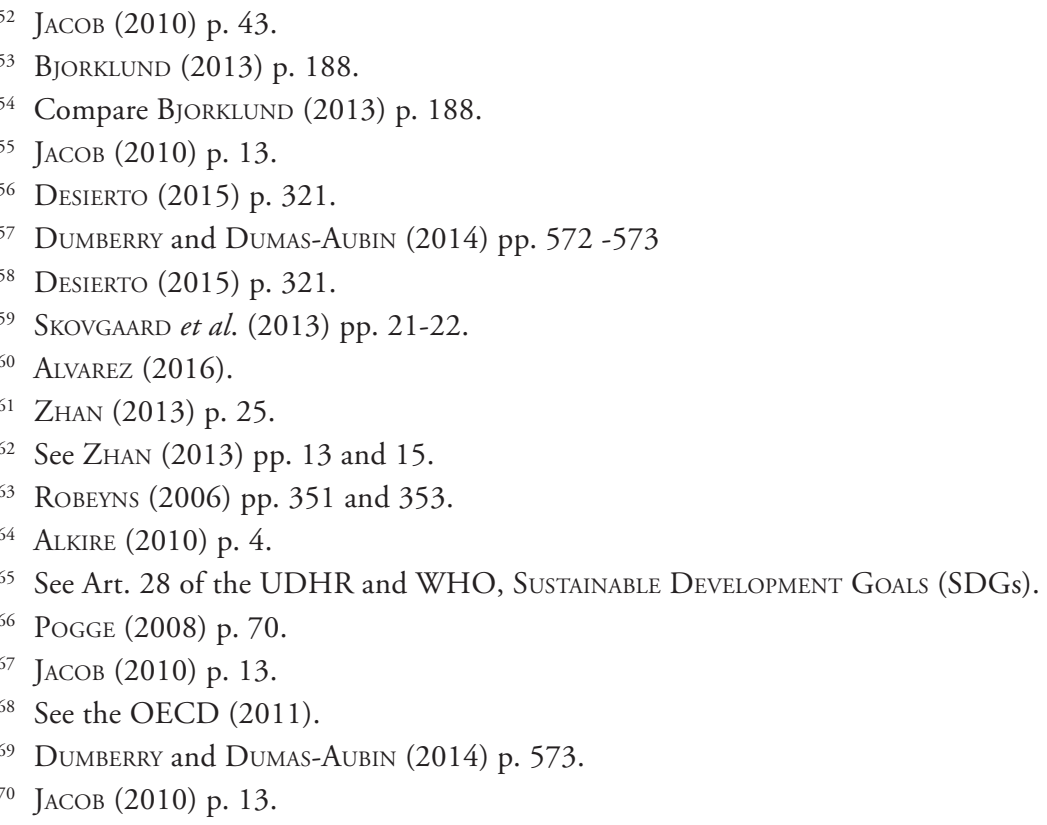


Thus, states can only bring "closely connected counterclaims" against them ${ }^{71}$. Indeed, traditional IIAs techniques "on the surface give too much power to investors" ${ }^{2}$. Notwithstanding, investment treaties are "an attempt to redress the power enjoyed by the state precisely because of its sovereign authority"73. "Without a treaty the state enjoys asymmetrical power vis-a-vis the investor" 74 . This is a practical reason that explains why the system evolved the way it did. States are sovereign to design rules and make investors comply with them in their territory. Conversely, without these treaties the investor would likely be in a disadvantaged position to defend themselves from state abuses.

Ergo, human rights are more likely to appear as a defense justifying state measures in IIDS $^{75}$, rather than independently invoked to safeguard human rights ${ }^{76}$. Notwithstanding, if a direct invocation was hypothetically allowed in IIDS, it is dubious that an ad-hoc arbitral tribunal constituted on a case-by-case basis by consent of the parties, would be competent to decide matters of human rights law arising out of the dispute $\mathrm{f}^{77}$. The tribunal's jurisdiction is defined in the agreement to arbitrate contained in the treaty or elsewhere ${ }^{78}$. One way of looking at this is to solely focus on the "precise formulation of the dispute resolution clause" wording in relation to the investment ${ }^{79}$. A different way of articulating the argument would be to point out that IIAs are not created in a "legal vacuum but in a system of public international law" $"$. In the latter option, arbitral tribunals may be able to integrate the dispersed obligations of states into the interpretative process through treaty interpretation techniques relying on article 31 (3)(c) of the Vienna Convention on the Law of Treaties (VCLT) ${ }^{81}$.

For instance, the tribunal in the Philip Morris v. Uruguay case acknowledged that the measure challenged was based on bona fide to protect public health and that Uruguay had constitutional duties in line with the objectives of the FCTC regarding health issues. Furthermore, the tribunal interpreted the fair and equitable treatment (FET) clause contained in the Switzerland-Uruguay Bilateral Investment Treaty (BIT) using the tools provided in article 31 of the VCLT "through the lens of broader international law" 82 , view which I share. In the Philip Morris v. Australia case, however, the applicable law might have been a concern had the tribunal not dismissed the claim due to admissibility issues. Article 10 of the Hong Kong-Australia BIT established that disputes should be submitted

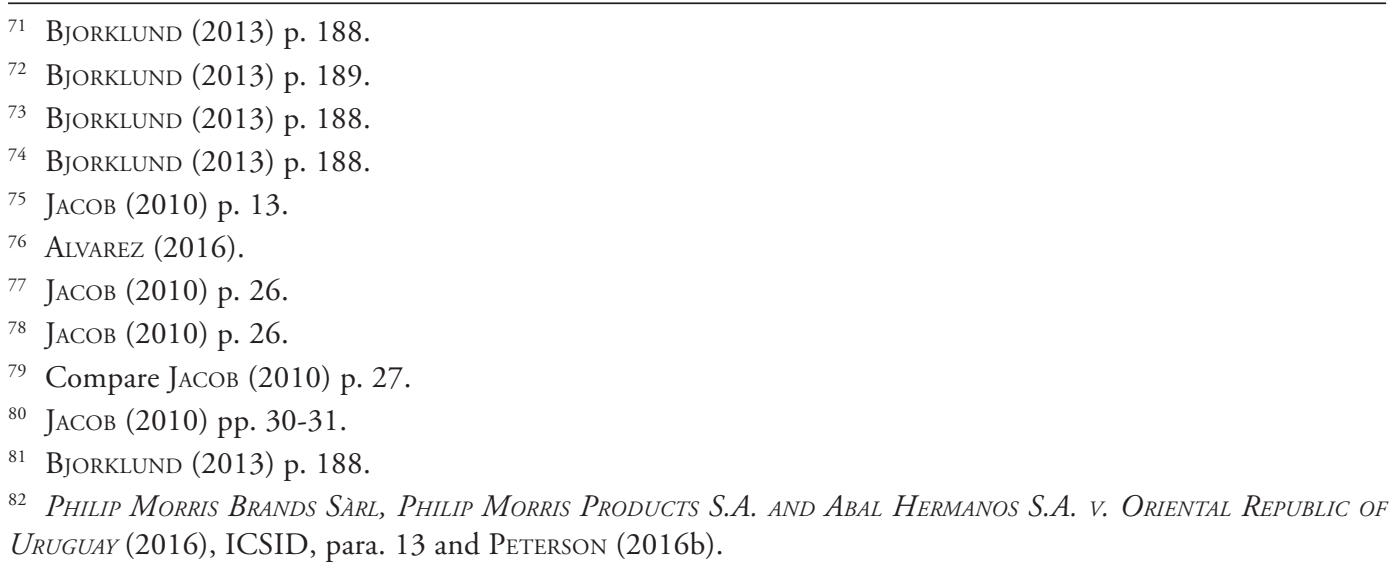


to arbitration under the UNCITRAL rules ${ }^{83}$. In turn, such rules enshrine that where no specific agreement by the parties can be found, "the arbitral tribunal shall apply the law which it determines to be appropriate" 84 . Given the elasticity in the applicable law and without a specific provision pertaining to the matter in the relevant BIT, it is uncertain if the tribunal would have considered or not the FCTC as part of the applicable law in the proceedings ${ }^{85}$.

Certainly, home states in similar situations could base their actions on article 2(1) of the ICESCR through the UN Protect, Respect and Remedy Framework and Guiding Principles on Business and Human Rights. The latter "articulates three core principles arising from international human rights treaty practices: 'the State duty to protect against human rights abuses by third parties, including business; the corporate responsibility to respect human rights; and the need for more effective access to remedies" "86. Still, for future cases such a path would be easier to reach if specific reference to the "other relevant rules" enshrined in article $31(3)$ (c) were found in the respective treaty ${ }^{87}$.

It is widespread knowledge that corporations can impact the realization of human rights ${ }^{88}$. Hence, it would be odd to suggest "that only states are bound not to violate human rights and all other entities may violate such rights at will" 89 . To avoid abuses, straight forward options such as including CSR clauses in treaties ${ }^{90}$, drafting model BITs ${ }^{11}$ or even opting for a sole multilateral investment agreement have been proposed ${ }^{92}$. In my view, these alternatives may shift attention away from the ultimate purpose of seeking such changes. To make reforms work, it is key to assess the supposed effectiveness a specific reform is expected to achieve and "what are the costs and benefits of relying on it", before any steps are taken ${ }^{93}$. If the aim is to protect the right to health, not solely because it falls under the scope of a given state's regulatory powers, but because it has a value in itself due to its possible effect on an individual's health, these are not necessarily the best techniques to undertake.

Even if the proposed "clean hands theory" is incorporated into the investment framework $^{94}$ or remedies are made available to those injured by corporations ${ }^{95}$, the preventive ambit of protection of the right to health linked to ill-health ${ }^{96}$ and the privation of an

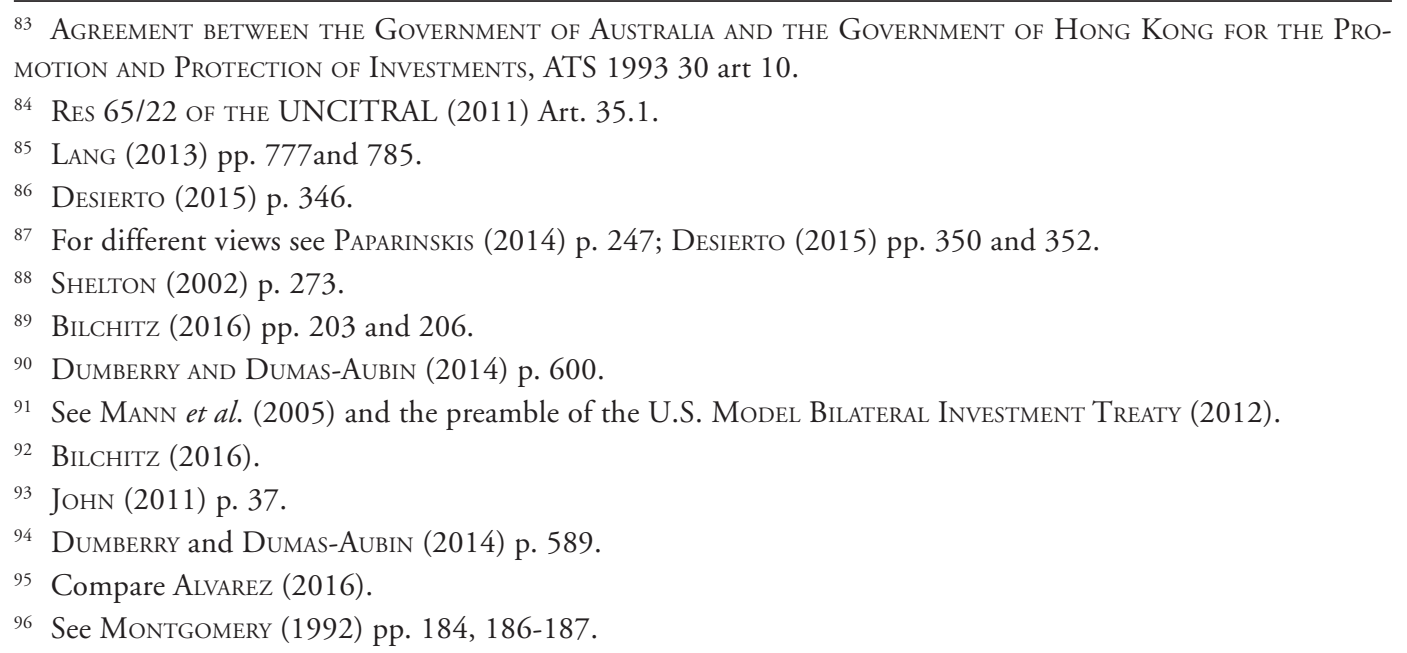


individual's control over their own health status will remain unprotected ${ }^{97}$. In a context in which both states and corporations are advocating for their own sake and where the host state might even be "complicit in the commission of human rights violations by a foreign corporation" ${ }^{\prime 98}$, third parties' legitimate interests to protect their own health are likely to be left without a voice.

\section{INTERNATIONAL INVESTMENT LAW: THE INNER SETTING}

This section examines the inner structure of IIL to highlight critical aspects that are likely to interfere with an individual's protection of their right to health.

\subsection{VAGUENESS IN THE PRIMARY RULE}

Despite the existence of more than 3000 bilateral investment treaties ${ }^{99}$, general applicable principles of IIL can be identified ${ }^{100}$. In practice, I share the view that two have been deemed as pivotal from a right-to-regulate perspective: provisions on expropriation and the FET clause ${ }^{101}$. Most of the investors' successful claims ${ }^{102}$ are based on these principles but it is often alleged that no clear definition can be found in indirect expropriation ${ }^{103}$ and that FET is too vague as a standard ${ }^{104}$. An initial issue, therefore, concerns the vague formulation of the primary rule in investment treaties ${ }^{105}$. The relationship between treaty language, expropriation and FET is reflected in the following scenario: a tribunal is likely to award damages for the breach of an investment treaty ${ }^{106}$. Where states exercise their right to regulate but regulation has a considerable negative impact on foreign investments, the investor may well challenge the state's measure under certain provisions ${ }^{107}$ : when there is no direct expropriation, a creeping or indirect expropriation can occur and when the latter is unclear, a FET breach is likely to be found ${ }^{108}$. Hence, having clarity between these factors is not only useful to present a good case but is key to assess if the state has actually breached primary obligations, giving raise to secondary obligations under ILC articles ${ }^{109}$. This assessment may end up with a generous interpretation of these elements, which would likely imply large compensations due by the states to investors. Conversely, if a narrow in-

\footnotetext{
97 Yamin (1996) p. 422. See also article 12 ICESCR.

98 Dumberry and Dumas-Aubin (2014) p. 572.

99 ZHAN (2013) p. 21.

100 SCHILl (2009) p. 69.

101 See the discussions in PARKerings-Compagniet V. Lithuania (2007), ICSID, section 8.3; MethaneX CoRpoRAtion V. United States (2005), UNCITRAL, Chapter IV B and Mann (2008) p. 20.

102 Dolzer and Schreuer (2012) p. 130.

103 OECD (2004) p. 3.

104 ЈАСОВ (2010) p. 45.

105 PAPARINSKIS (2013a) p. 628.

106 SKOVGAard et al. (2013) p. 19.

107 ЈАСОВ (2010) p. 13.

108 Peterson (2016b).

109 See Crawford (2002) pp. 874, 876
} 
terpretation of the same provisions is held, this may imply the investor losing their right to be compensated for states actions interfering directly with their investments. Thus, the way in which some key principles or provisions are contemplated will ultimately have a direct impact on the outcome of the case ${ }^{110}$.

To illustrate, in the Methanex v. Unites States case, the investor claimed damages of US $\$ 970$ million for the regulatory ban on a gasoline additive ${ }^{111}$. Relying on the Metalclad v. Mexico decision, Methanex alleged that the US regulatory measure breached Article 1110 of NAFTA and had such an economic impact on their investment that it was tantamount to expropriation and required compensation ${ }^{112}$. The tribunal, however, drew a sharp line holding that "regulatory measures that are for a public purpose, non-discriminatory and enacted in accordance with due process are not, by definition under international law, expropriations. Not being expropriations or measures tantamount to expropriation, they are not, therefore subject to any compensation"113. In this case, the Tribunal embraced a broad policy approach to assess policy powers ${ }^{114}$ and held that "the California ban was a lawful regulation"115.

The examples of Methanex and Metalclad highlight the divergent approaches to this same issue: Metalclad relied on the economic impact of the measure whereas Methanex preferred to focus on the purpose of the measure taken without even addressing the factor contemplated as critical in the Metalclad's case ${ }^{116}$. Notwithstanding, factors such as "the economic impact of the government action; the extent of interference with distinct, reasonable investment backed expectations; and the character of the government action" are all elements that are likely to be considered in the assessment of other cases ${ }^{117}$.

As an additional point to highlight, the Methanex tribunal seemed to rely on the inexistence of a specific commitment as the turning point when deciding the case ${ }^{118}$. However, due to the critical importance of health issues, one may well think of a state arguing that the situation falls under the doctrine of rebus sic stantibus, and rely on a fundamental change in circumstances to explain that the undertakings can no longer be applicable ${ }^{119}$. Nevertheless, due to the exceptional application of this doctrine and the strict requirements set forth in VCLT article 62, this would be a risky move by the state ${ }^{120}$. Another option may be to ask the arbitral tribunal for "reduced compensation for environmental and human rights measures"121. In my view, this is a difficult approach to embrace for practical reasons. Most

\footnotetext{
110 EFILA.

111 Methanex V. United States (2005), UNCITRAL, Part I Preface para. 1.

112 MANn (2005).

113 MANn (2005).

114 MANN (2005).

115 Methanex V. United States (2005), UNCITRAL, Part IV, Ch D Article 1110 NAFTA, para. 15.

116 MANn (2005).

117 MANN (2005).

118 Methanex V. United States (2005), UNCITRAL, Part IV, Chapter D Article 1110 NAFTA, para. 7.

119 ManN (2005).

120 Dennis and Chamberlain (1932) pp. 53 and 67.

121 Mann (2008) p. 21.
} 
tribunals have rejected it on the grounds that "all expropriations are for a valid public purpose, yet still subject to proper levels of compensation defined in the IIAs themselves once the measure is found to be an expropriation"122. Moreover, to suggest that some human rights issues can be treated as "exceptions to compensation rules" would imply to hierarchically organize public values, which is not endorsed neither in "law or policy today"123.

In the Philip Morris v. Uruguay case, a different issue attracted public attention; the possibility of having an investor claiming compensation "for losses of expected profits" in cases where rules applied by the state seem to be "non-discriminatory" and profits appear to be gained from "causing public harm"124. Philip Morris held that mandatory "large warning labels on cigarette packs prevent it from effectively displaying its trademarks"125, causing a remarkable decrease in their sales, which in turn, led to a substantial loss of market share ${ }^{126}$. They alleged that article 1 of Ordinance 514 of Uruguay mandating graphic images to illustrate the adverse health effects of smoking were not designed to warn of the actual health effects of smoking but to harvest fear and spread horror. Thus, they argued that the measure was not the best way to promote health policies ${ }^{127}$. When states face these types of allegations, the manner in which arbitrators conceive legitimate expectations will be crucial. To consider them as an inherent and core part of property rights or as a factual reality deserving protection from the application of the rule of law would likely shift the outcome of the case ${ }^{128}$. Consequently, the precise idea of whether the rule of law entails a merely formal idea or embrace a substantive dimension may well vary ${ }^{129}$. Hence, different perspectives of arbitrators ${ }^{130}$ originating from a variety of legal backgrounds ${ }^{131}$ might have a direct impact on determining whether the state has breached their primary obligations. Since some tribunals have unduly relied on legitimate expectations of investors to render awards ${ }^{132}$ this issue should not be underestimated. Just as investors deserve an adequate degree of "protection from expropriation or discriminatory regulations" 133 , taxpayers deserve protection too. When health issues arise, it does not seem sensible to make them pay twice: first for their health damage, and then to compensate the investor "for their lost profits when the government stepped in to regulate a dangerous product" 134 . This situation took one annulment committee to clarify that " $[\mathrm{t}]$ he obligations of the host State towards

122 Metalclad Corporation v. United Mexican States (2000), ICSID, para. 103, 111 and Mann (2008) p. 21.

123 Mann (2008) p. 21.

124 Stiglitz and Hersh (2015) p. 2.

125 Eberhardt and Olivet (2012) p. 13.

126 Philip Morris Brands Sarl, Philip Morris Products S.A. and Abal Hermanos S.A. v. Oriental Republic of URUGUAY (2016), ICSID, Annex A para. 8.

127 Philip Morris Brands Sarl, Philip Morris Products S.A. and Abal Hermanos S.A. v. Oriental Republic of URUGUAY (2016), ICSID, Annex A, para. 5.

${ }^{128}$ See Waldron (2012) pp. 55 and 74.

129 Waldron (2012) p. 42. Compare the American and the UK's view of the rule of law.

130 Mills (2011) pp. 469-503.

131 Dumberry and Dumas-Aubin (2014) p. 598.

132 Paparinskis (2013a) p. 628.

133 Stiglitz and Hersh (2015) p. 2.

134 Stiglitz and Hersh (2015) p. 2. 
foreign investors derive from the terms of the applicable investment treaty and not from any set of expectations investors may have or claim to have"'135. The annulment committee stressed on the wording and the provisions of the relevant investment treaty regarding this issue $^{136}$. This is similar to the customary rules of treaty interpretation ${ }^{137}$.

However, when clauses are unspecific, they give arbitral tribunals significant discretion $^{138}$. Regarding the FET standard, it has been suggested to clarify whether FET is a restatement of international customary law or whether they impose an autonomous treaty standard. Another proposed path has been to enunciate "categories of FET breaches" that can give raise to state responsibility ${ }^{139}$. These solutions are thought to diminish state exposure to liability for actions taken in the public interest.

Nevertheless, even if treaties contained examples of both possible violations and situations in which the standard is not violated ${ }^{140}$, it would be "impossible to spell out all forms of unfair and inequitable treatment in a tidy formulation" to pre-determine which conducts are likely to trigger the state liability ${ }^{141}$. Furthermore, treaty interpretation takes place by ad-hoc tribunals with a variable composition for each case $\mathrm{e}^{142}$ in a system where although precedent has some weight, it lacks strong respect ${ }^{143}$. The latter renders it considerably difficult to unify the views of rule-interpreters on key matters such as the material content of the rules ${ }^{144}$, the desired degree of deference towards host state measures, or the way in which treaty interpretation rules should be applied ${ }^{145}$. This is a plausible explanation to understand that relying on the proportionality principle ${ }^{146}$ does not provide us with a real solution to protect the right to health either. As an alternative, some scholars have advocated for substantive consensus ${ }^{147}$ or even legal training for arbitrators ${ }^{148}$. However, it is unclear that a uniform view on key issues of investment law is even desirable ${ }^{149}$ where an uneven playing field in the bargaining power of smaller economies might exist ${ }^{150}$.

With the aim of limiting the scope of critical treaty provisions, some states have implemented solutions such as joint statements or lengthy interpretation notes aiming to guide tribunals in the interpretation process ${ }^{151}$. In a way, this option limits the freedom of

35 MTD EQUITY SDN BHD. AND MTD CHILE SA v. CHILE (2007), ICSID, para. 67.

136 SKovgaard et al. (2013) p. 17.

137 Weiler and Investment Treaty Counsel (2010)

138 BJoRKLUNd (2013) p. 178.

139 ЈАСОВ (2010) p. 35.

${ }^{140}$ ЈАСОВ (2010) p. 45.

${ }^{141}$ JАСОВ (2010) p. 35.

142 Dolzer and Schreuer (2012) p. 28.

143 Dolzer and Schreuer (2012) p. 19.

144 JАСОв (2010) p. 41.

145 Desierto (2015) p. 352.

146 SCHILL (2009) ch VI.

147 BJorklund (2013) p. 190.

148 Stevens (2013) p. 247.

149 BJorklund (2013) pp. 178 and 197.

150 Alvarez (2016).

151 Mann (2008) p. 24. 
interpretation of tribunals, which should be safeguarded in the sense that many concepts in international law are intentionally left open to adapt to different times and situations ${ }^{152}$.

Other attempts by states to address their regulatory space ${ }^{153}$ can be seen in the "new generation of BITs" that were concluded from 2003 onwards ${ }^{154}$, such as the US Model BIT, the U.S.-Central America Free Trade Agreement; the new Model Canadian BIT and the TTIP, among others ${ }^{155}$. Indeed, properly drafted, specific provisions could strengthen policy powers. However, in most cases, such paragraphs are written in a useless way to adequately protect the right to regulate. A clear depiction can be found in the European Free Trade Association-Singapore Agreement in which a specific provision entitled "Domestic regulation" can be found and reference is made to the UDHR. The phrase in article 43 stating "any measure [...] that is in the public interest" seems to embrace a broad scope of action for the state. From a regulatory perspective, however, the phrase immediately following in article 43, "consistent with this Chapter" is disappointing ${ }^{156}$. In practice, exactly the opposite is enshrined: the state is allowed to safely regulate for a public purpose only in a manner consistent with the IIAs protecting the foreign investor" 157 .

\subsection{FIRST MOVERS: A RISKY CHOICE}

There is no doubt that " $[\mathrm{t}]$ he right of states to regulate is an inherent aspect of state sovereignty" ${ }^{158}$ nevertheless the limitation of such exercise through treaties or customary law is one of the purposes of international law ${ }^{159}$. Notwithstanding, when adopting a given policy measure each state may have different views of its appropriateness ${ }^{160}$. Likewise, perceptions on the quality of the measure and its legitimacy may well vary ${ }^{161}$.

The current challenge for investment policymakers is to provide an offset of measures to entice foreign investment while stressing sustainable development. Hence, in seeking an adequate balance between liberalisation and regulation, the latter has acquired a predominant role ${ }^{162}$. If a state overemphasises on regulation and the "regulatory environment" becomes tough, the capacity of such states to compete with other states by applying laxer standards to attract foreign investment may decrease ${ }^{163}$. In connection with this regulatory environment, it has been argued that if an investment treaty is ignored a state will not experience any decrease in its policy space ${ }^{164}$. Notwithstanding, the risk of being

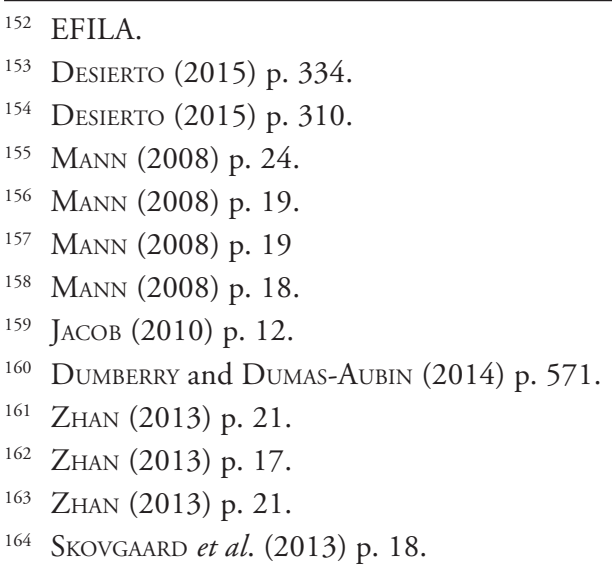


exposed to the expenses of investment proceedings ${ }^{165}$ and facing the costs of an adverse arbitral award ${ }^{166}$ might be an additional hurdle when adopting novel legislation or measures negatively impacting on an investor's right ${ }^{167}$.

In a context, in which many corporations are larger than national economies and control more than a quarter of the world's economic activity ${ }^{168}$, some states may well be disempowered to modify their laws or to adopt specific measures, even for legitimate welfare purposes ${ }^{169}$.

I believe that what is more critical from a health perspective is that investment treaties may restrain states "from regulating in ways that it would otherwise regard as desirable" 170 . Hence, the political cost of an investment treaty needs to be measured by the extent to which it precludes a given state from implementing policies that it would prefer to adopt in the absence of such agreements ${ }^{171}$. The question that should be raised, therefore, relates to the dissuasive power that an investment treaty may have on decision-makers to pursue preferred policies by the existence of such treaty ${ }^{172}$.

It is interesting to note that Australia was the first country in the world requiring cigarettes to be sold in plain packaging. The Philip Morris v. Australia award was rendered in December 2015 and in May 2016, the UK, Ireland and France followed, passing similar legislation. Both the UK High Court and the European Court of Justice upheld similar directives on tobacco products and endorsed the lawfulness of the measure when challenged ${ }^{173}$. Nonetheless, the risk of a negative cascade impact could be envisaged too. For instance, Canada, under the threat to be subject to an international proceeding such as Australia and Uruguay, retreated from adopting similar legislation some years ago ${ }^{174}$. Where current levels of tobacco consumption are "expected to kill up to ten million people per year by 2030 " and with estimations of tobacco as "the leading cause of premature mortality in industrialized nations, but also the leading cause of avoidable death worldwide" for the following years, the latter prediction seems critical for health purposes ${ }^{175}$.

Another significant first-mover obstacle that states may face when protecting the right to health is the difficulty to convince the tribunal of the effectiveness of a given innovative measure ${ }^{176}$. For instance, in the Chemturra v. Canada case, the tribunal analysed the legality of Canada's ban on lindane, a pesticide used in the production of canola ${ }^{177}$. At issue

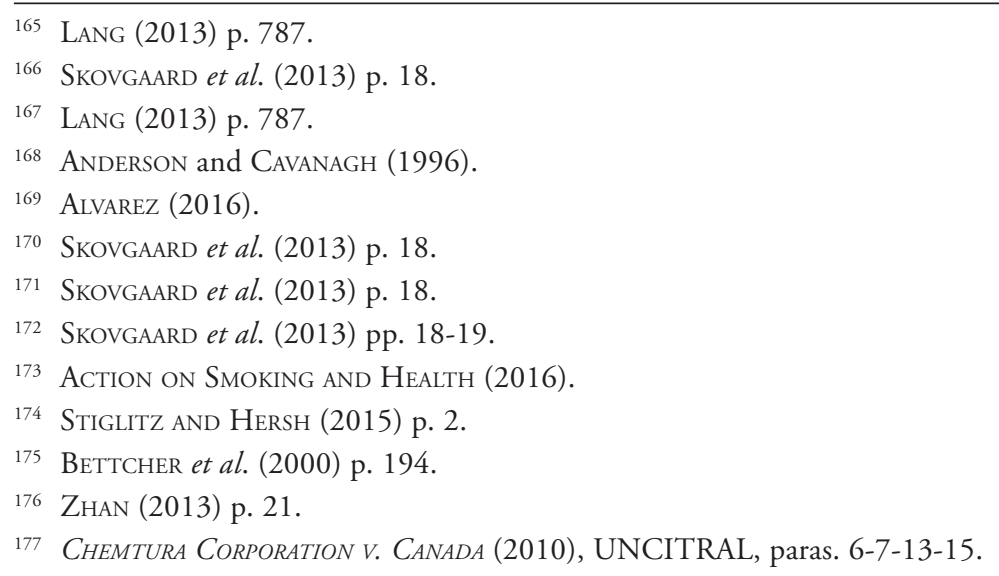


was the valid exercise of Canada's policy powers driven by the widespread awareness of pesticide dangers to human health and the environment ${ }^{178}$. The tribunal held that the interference was "not substantial enough to be considered as an expropriation" and acknowledged that since the complaint was related to policy powers, it was not a compensatory taking ${ }^{179}$. The final award was successful from a health protection perspective. The reasoning of the tribunal, however, showed an overreliance on previous bans of the pesticide in other countries to justify its decision on the grounds that the restriction at stake was not a unilateral state action but a widespread progressive restriction from 1970 onwards ${ }^{180}$. Thus, it is hazy if the same conclusion would have been reached by the tribunal had Canada been a pioneer in banning the pesticide on health grounds ${ }^{181}$. This first-mover issue was addressed in the recent Philip Morris v. Uruguay case too. The award noted that "a state is entitled to be a first-mover when it comes to enacting novel regulation that are not yet seen in other jurisdictions, so long as these have some rational basis and are not discriminatory" ${ }^{182}$. However, it is unclear if this decision was unanimous ${ }^{183}$. Arbitrator Gary Born, in his dissenting opinion, explained that the "unprecedented" measures taken by Uruguay went unreasonably far since no other state had adopted a single presentation requirement (SPR) for tobacco advertisement. Regardless that both the WHO's and the Pan-American Health Organization's amicus curiae briefs endorsed the SPR measure and defended its potential effectiveness as a means to protect public health ${ }^{184}$, he argued that such a measure deviated from the "global regulatory baseline". He continued, contending that it was disproportionate and that its effectiveness was not evidenced-based for the specific purpose sought, thus undermining the FET standard ${ }^{185}$. In his reasoning, Mr. Born acknowledged the need for deference towards state decisions but took particular care to highlight that such deference (depicted by a state's discretion or judgment) should be carefully and closely examined by arbitrators ${ }^{186}$.

Whilst there is increasing respect for policy powers in terms of state health measures since awards from 2000 onwards $^{187}$, this does not imply that the right to health is adequately protected in investor-state arbitrations. Indeed, Uruguay's bona fide desire to protect public health in accordance with its own constitution and its international obligations

\footnotetext{
178 Chemtura Corporation v. CANAda (2010), UNCITRAL, paras. 135-136.

179 Chemtura Corporation v. CANADA (2010), UNCITRAL, paras. 265.

180 Chemtura Corporation v. CANAdA (2010), UNCITRAL, paras. 6-135-136.

181 International Investment Arbitration + Public Policy (2011).

182 See also Philip Morris Brands Sarl, Philip Morris Products S.A. and Abal Hermanos S.A. v. Oriental RePUBLIC OF URUGUAY (2016), ICSID Annex A para. 430.

183 See Peterson (2016b).

184 Philip Morris Brands Sàrl, Philip Morris Products S.A. and Abal Hermanos S.A. v. Oriental Republic of Uruguay (2016), ICSID, Concurring and Dissenting Opinion, para. 126.

185 Philip Morris Brands Sàrl, Philip Morris Products S.A. and Abal Hermanos S.A. v. Oriental Republic of Uruguay (2016), ICSID, Concurring and Dissenting Opinion, para. 5.

186 Philip Morris Brands Sàrl, Philip Morris Products S.A. and Abal Hermanos S.A. v. Oriental Republic of Uruguay (2016), ICSID, Concurring and Dissenting Opinion, para 126 and Hepburn (2016).

187 See Peterson (2016a).
} 
was not an issue for the tribunal in this case ${ }^{188}$. Conversely, for one of the arbitrators, the ultimate issue was the individual impact of the introduced measure taken in isolation. Nevertheless, it was not sufficient for all arbitrators to note that the smoking rates in Uruguay had dropped and that the measure at stake was a public health measure designed for that very purpose ${ }^{189}$. For the dissenter, if the SPR was actually an effective means, it would have been contemplated in the FCTC or at least suggested in its implementation guidelines ${ }^{190}$.

In my view, this last point does not imply that pioneer regulation cannot be adopted but the applicable threshold to evaluate the reasonableness and effectiveness of the measure at stake is excessively high. Moreover, as the tribunal noted, there might be serious methodological limitations to determine the actual impact of a given policy when adopted within a broader set of measures with the same purpose ${ }^{191}$. I posit, it is difficult to evaluate such an impact and determine whether the alleged company losses are due to the state's measure or other factual circumstances such as a mere change in consumers' lifestyle preferences.

\section{TOWARDS A MORE REALISTIC PROTECTION OF THE RIGHT TO HEALTH}

To face the outlined challenges, some states have started a review process of their IIAs or have gone a step further by denouncing and terminating them ${ }^{192}$. Yet, such efforts are likely to be diluted. From a technical perspective, it is possible to think of treaty amendments. In practice, this is a process implying several difficulties.

On the one hand, given the variety of IIAs, it does not seem reasonable "to pre-identify each individual treaty provision that triggers the issue of a State's regulatory freedom to pursue public interest or human rights concerns" ${ }^{193}$. In addition, it might be hard to amend multilateral agreements in which many states parties are involved ${ }^{194}$. On the other hand, many BITs cannot be terminated for ten years or more ${ }^{195}$ and even if they were so, existing investors would remain protected for an additional period of ten or twenty years thereafter ${ }^{196}$. Thus, a "treaty-by-treaty piecemeal approach" to renegotiate old treaties is unlikely to be the most effective response ${ }^{197}$ : negotiations take time and in the meanwhile the right to health will still be subject to the framework set by older treaties ${ }^{198}$.

\footnotetext{
188 See Philip Morris Brands Sarl, Philip Morris Products S.A. and Abal Hermanos S.A. V. Oriental Republic of URUGUAY (2016), ICSID paras. 121-132 and PETERSON (2016a).

189 Philip Morris Brands Sarl, Philip Morris Products S.A. and Abal Hermanos S.A. V. Oriental Republic of URUGUAY (2016), ICSID para. 136 and PETERSON (2016a).

190 Philip Morris Brands Sàrl, Philip Morris Products S.A. and Abal Hermanos S.A. v. Oriental Republic of Uruguay (2016), ICSID, Concurring and Dissenting Opinion, para 100 and Hepburn (2016).

191 Peterson (2016a).

192 ZHAN (2013) p. 26.

193 Desierto (2015) pp. 310-311.

194 ЈаСОВ (2010) p. 33.

195 See article 13(2)-(3) of the German Model Treaty 2008.

196 Alvarez (2016).

197 ZHAN (2013) p. 27.

198 ЈасОв (2010) p. 33.
} 
It is interesting to reflect on how the most favoured nation (MFN) clauses can come into play with new "development-friendly provisions"199. Although MFN clauses are most commonly triggered in practice in the framework of dispute resolution mechanisms ${ }^{200}$, they may well be used to import other substantive standards where the basic treaty wording allows to do so $^{201}$. Article 4 of the ILC Draft Articles on MFN clause states that, "[a] most-favoured-nation clause is a treaty provision whereby a State undertakes an obligation towards another State to accord most-favoured-nation treatment in an agreed sphere of relations"202. If the rationale behind MFN clauses is to guarantee "treatment", it would be essential to consider not only the actual wording of the clause but the scope of the word treatment; its coverage and its beneficiaries to revise its applicability in a given treaty framework ${ }^{203}$. In draft article 5, treatment is defined as "(..) treatment accorded by the granting State to the beneficiary State, or to persons or things in a determined relationship with that State, not less favourable than treatment extended by the granting State to a third State or to persons or things in the same relationship with that third State"204. Under IIAs, if states generally offer MFN treatment not just to other states, but also to investors or investments of the other state, claims from investors to be provided with more favourable treatment granted to other investors or investments under older treaties, could be envisaged $^{205}$. Thus, the questions that inevitable flows are how these higher standards drafted to incorporate new values will come into play with pre-existing treaties and if they actually will be applied as it is originally contemplated ${ }^{206}$. For instance, article 1.2. of the TransPacific Partnership (TPP), sets forth that the TPP will coexist with existing international agreements ${ }^{207}$. The investor, therefore, might prefer to raise a claim under another BIT either to avoid stricter standards on new treaties or because it is more beneficial for their case as a whole ${ }^{208}$. Again, the interpreter's view ${ }^{209}$ on issues such as whether "treatment" refers to a third party's overall treatment or solely to partial treatment relying on a specific provision or even a part of the clause at stake will be key ${ }^{210}$. This would also be the case when reviewing MFN clauses and whether the investor actually has "a 'claim' in itself or simply a 'right to claim"'211. Thus, even if there is an increased scope for government action ${ }^{212}$, a reduced

\footnotetext{
199 ZHAN (2013) p. 27.

200 FietTa (2005) p. 131.

201 Dumberry (2016).

202 ILC (1978).

203 ILC (1978).

204 ILC (1978).

205 ZHAN (2013) p. 27.

206 Cortés (2016).

207 See TPP (2016).

208 Cortés (2016).

209 ILC (1978) p. 180.

210 Dumberry (2016).

211 Dumberry (2016).

212 Desierto (2015) p. 310.
} 
scope for investors' right ${ }^{213}$ and improved accountability of investors in new treaties ${ }^{214}$, the right to health may still be undermined.

Calls have been made for a "more coordinated and cooperative approach" 215 to fulfil the need for "rebalancing" the private and public interest involved" ${ }^{216}$. If " $[\mathrm{w}]$ hat matters is the bigger picture" 217 , the question should be whether international law is well equipped to address the challenges regarding the main public health problems of this century ${ }^{218}$. It has been frequently argued that there are "hardly any mechanisms for coordination between IIL and other parts of the global economic system"219. Nonetheless, the WHO's general competence regarding health issues and the precautionary principle, are two less explored paths that might contribute to enlighten the debate and help to indirectly protect the right to health.

\subsection{THE WHO: A SLEEPING GIANT}

Article 1 of the WHO's Constitution sets forth that the objective of such organization is the "attainment by all peoples of the highest possible level of health". Thus, in accordance with its constitutional mandate, all health-related matters are encompassed within the competence of the WHO. Although the WHO has been lately identified with the proposition of conventions and regulations ${ }^{220}$, I posit that article 2 provides a variety of tools for the organization to achieve its objective. Specifically, article 2(a) allows the organization "to act as the directing and co-ordinating authority on international health work" and articles 2(b) and 2(v) allow the authority "to establish and maintain effective collaboration with the United Nations, specialized agencies, [...] and such other organizations as may be deemed appropriate" and to generally "take all necessary action to attain the objective of the Organization", respectively.

In turn, the International Court of Justice (ICJ) is defined in article 1 of its statute as "the principal judicial organ of the United Nations". Thus, through the WHO's mandate I propose to engage the ICJ in those investor-state arbitration proceedings in which health-related matters are at stake in order to attain a more realistic protection of the right to health. Although article 34 of the ICJ statute establishes that "[o]nly states may be parties in cases before the Court", the type of engagement we are seeking from the ICJ for these cases will be solely related to its advisory role, so I believe no serious issues should be raised regarding their performance. Article 65 of the ICJ statute allows the Court to give advisory opinions "on any legal question at the request of whatever body may be authorized by or in accordance with the Charter of the United Nations to make such a request". This is applicable to the WHO, which has "institutional authority" and a direct interest to

\footnotetext{
213 Alvarez (2016).

214 ZHAN (2013) p. 26.

215 ZHAN (2013) p. 27.

216 Desierto (2015) p. 310.

217 ЈАСОв (2010) p. 36.

218 Bettcher et al. (2000) p. 193.

219 ZHAN (2013) p. 22.

220 WHO Constitution Art. 2(k).
} 
ask the ICJ for an advisory opinion on specific legal questions regarding ongoing international disputes within the scope of its activities ${ }^{221}$. Consequently, the ICJ has the prerogative to respond to such request and a duty to answer in accordance with its own statute ${ }^{222}$. The aim would be to assist arbitrators in a "reflexive engagement" in a context of a fragmented international legal order ${ }^{223}$ where significant doubts regarding entitlements, duties, the object of certain human rights ${ }^{224}$ and even the applicable law, remain ${ }^{225}$. Hence, the ICJ's intervention would be a non-binding, advisory opinion in which no position would be taken on the merits of the underlying dispute ${ }^{226}$. Its performance might shed light on issues such as systemic integration, and interpretation regarding potential conflicting clauses of a variety of regimes or might answer specific legal questions regarding customary international law and other international instruments or bodies if needed ${ }^{227}$. The questions addressed to the Court, however, will need to be carefully drafted and should not trespass on decisions of legality issues linked to a given measure or a specific situation ${ }^{228}$. Instead, questions should remain within the boundaries of "lesser political sensitivity"229 and answers should be addressed with the appropriate view of a judicial and not a political body ${ }^{230}$.

Since, a cautious role is expected from the ICJ, objections from other international actors are unlikely to be successfully raised ${ }^{231}$. In my view, whilst objections may not be raised, this does not necessarily imply that the proposed approach will be welcomed. The WHO's participation in such proceedings imply an amicus curiae submission which needs, in first place, to be accepted by the arbitral tribunal in accordance with the applicable procedural rules. In addition, a cooperative attitude from decision-makers is required to enhance the results. The more arbitrators acknowledge the variety of perspectives of other systems of law involving different goals in IIDS, the more aware they will be regarding the external impact of their decisions for other regimes. In turn, as Lang insinuates, the keener they will be to embrace this possibility with an open mind $^{232}$.

Engaging the ICJ could entail systemic benefits and address some of the problems disclosed above ${ }^{233}$. ICJ proceedings enjoy high transparency standards and, in exercising its advisory jurisdiction, they may receive insights from a broad scope of actors which may be a valuable input to appropriately highlight the "externalities" of IIDS ${ }^{234}$ from a body which

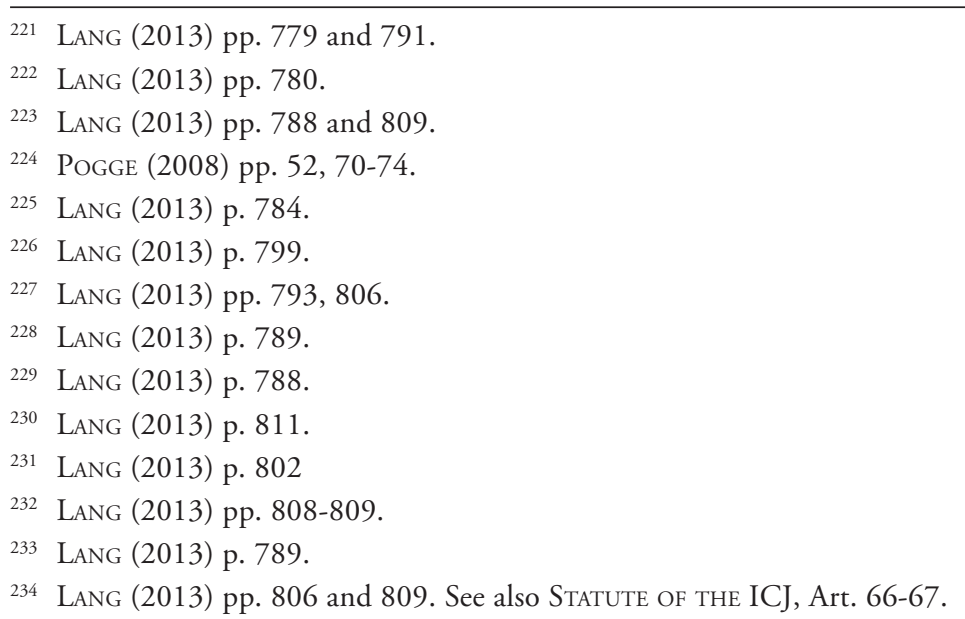


carries strong weight and moral authority in international law ${ }^{235}$. I can envisage that critics may argue that the additional costs and delay issues are serious drawbacks to embrace this option. Others may put forward concerns regarding the decrease of one of the alleged main advantages of arbitration, namely, confidentiality ${ }^{236}$. Nevertheless, given the sensitivity of health matters, I share the view that transparency should be the guiding principle in those cases where human rights and public interest are at stake $\mathrm{e}^{237}$.

\subsection{THE PRECAUTIONARY PRINCIPLE: A PROSPECTIVE GUIDANCE}

Sufficient protection from health risks is crucial for human development ${ }^{238}$. Accordingly, the right to health has been internationally recognized in a wide variety of human rights conventions. Regional instruments might differ in the wording chosen to enshrine such a right but they all aim to protect health as a subject matter ${ }^{239}$.

In practice, the core guiding principles have been prevention and precaution ${ }^{240}$. Thus, the foundations of public health contemplate distinguishing and avoiding risks to human health as well as identifying and implementing protective action ${ }^{241}$. The latter has provided room for the development of principles aiming to address human activities entailing health risks ${ }^{242}$.

Specifically, the precautionary principle has contributed to the understanding that "in cases of serious or irreversible threats to the health of humans or ecosystems, acknowledged scientific uncertainty should not be used as a reason to postpone preventive measures" 243 . This dimension of the precautionary principle is mainly addressed to policymakers at a domestic and international level ${ }^{244}$. The underlying idea is that "[a]lthough human activities cannot be risk-free, precaution can stimulate more health-protective decision-making under uncertainty and complexity" ${ }^{245}$.

The benefit of this approach is that this principle seems to adequately embrace and cover the preventive scope of the right to health in accordance with the scientific information available at a given time ${ }^{246}$. However, this principle has a procedural dimension too; laying the foundation for "a shift in the onus of proof to those who propose potentially harmful activities"247. In my view, this specific dimension is the more interesting one from

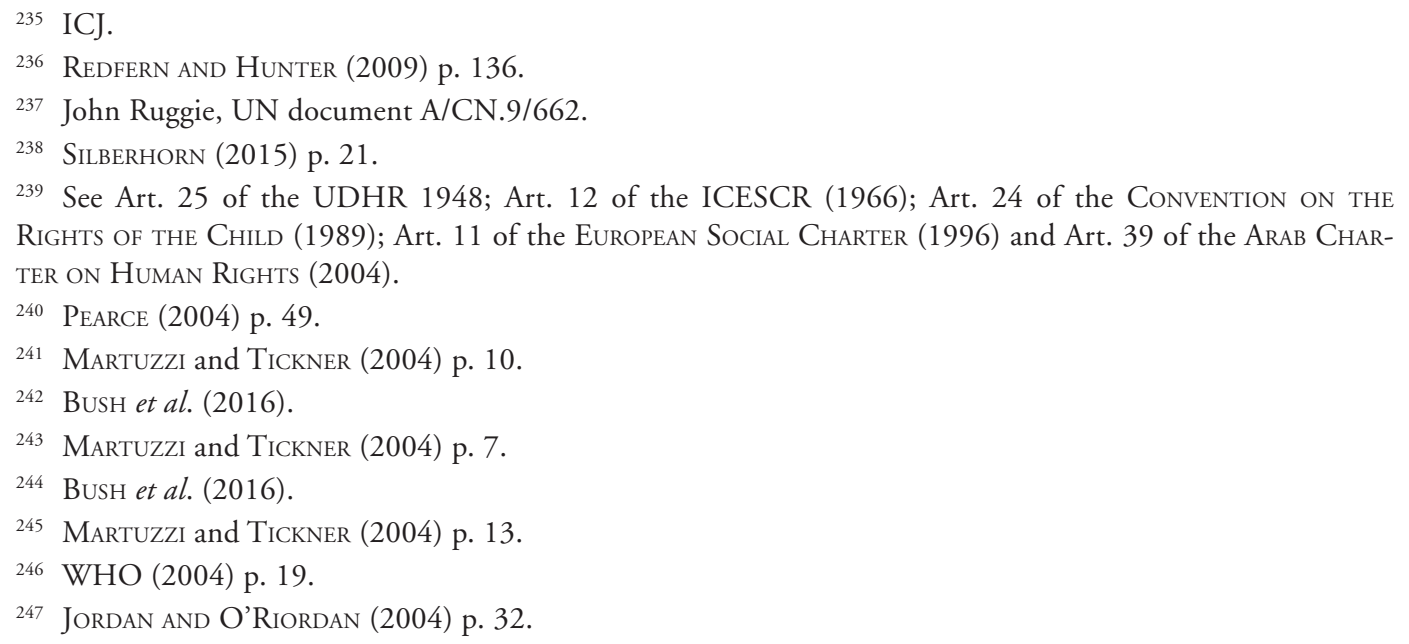


the IIDS perspective. The precautionary principle establishes that where there is a threat of serious damage, the burden of proof for those potentially harmful actions is shifted in the context of scientific uncertainty ${ }^{248}$. I believe the latter is in line with the acknowledgement that it takes time to obtain long-term effects and, hence, "[s]cientific evidence does not always advance quickly enough to establish absolute cause and effect due to uncertainty" ${ }^{249}$.

The procedural dimension is the most questioned one in policy terms, given its linkage to excessive innovation barriers ${ }^{250}$. If applied to IIDS, however, I believe such concerns should be vanished because the application of the principle will often occur in a reactive manner: when the dispute has already arisen after people have already been exposed to the risk $^{251}$. If this principle were applied to health issues in IIDS, the focus would likely shift from the state proving the specific effectiveness of a given measure, to the investor having to demonstrate that the investment at stake does not cause harm to citizens where there are "reasonable scientific grounds for concern" 252 .

In my view, the shift in the onus probandi is more likely to provide the desired balance between "issues of power, ownership and, ultimately, protection of health" ${ }^{253}$. It may also endorse a human-centered approach to dealing with unforeseen situations arising after the conclusion of IIAs by strengthening and rebalancing duties of states and other international actors to prevent harm. Thus, the precautionary principle could contribute to a better distribution of risks without undermining the confidence already gained in IIDS or precluding compensation for the investor. Furthermore, this principle is likely to contribute to consistency in IIDS if in all health-related cases the same approach is used. Certainly, outcomes may still differ due to the specific facts surrounding the case, but using the same framework would highly contribute towards predictability without undermining flexibility ${ }^{254}$.

Despite the advantages that the application of this principle offers for the right to health protection, trespassing the boundaries of policymaking and pervading into IIDS will be a new challenge. This principle has expanded to a variety of countries through international agreements ${ }^{255}$. Countries such as the US and the UK, have included elements of precautionary thinking in some of their policies ${ }^{256}$. Moreover, its inclusion in the 1992 Maastricht Treaty on European Union and the 1990 Dublin Declaration of the European Council $^{257}$ signifies its adoption as a European legal norm, used mainly in international environmental policy ${ }^{258}$.

\footnotetext{
248 Goldstein (2001) p. 1358.

249 Bush et al. (2016).

250 Martuzzi and Tickner (2004) p. 13.

251 Bush et al. (2016).

252 WHO (2004) p. 21.

53 Martuzzi and Tickner (2004) p. 10.

254 WHO (2004) p. 24.

255 Martuzzi and Tickner (2004) p. 10.

256 Jordan and O'Riordan (2004) p. 33

257 JORDAN and O'RIORDAN (2004) p. 38.

258 WHO (2004) p. 31.
} 
In addition, the European Commission has provided a "clear set of guidelines" drawing the contours and implementation of the principle in accordance with other international rules ${ }^{259}$, and it has been largely developed by the European Court of Justice, the World Trade Organization and the $\mathrm{WHO}^{260}$. Similarly, it is enshrined in principle 15 of the 1992 Rio Declaration on Environment and Development (Rio Declaration), signed by over 170 countries $^{261}$. Principle 1 of the Rio Declaration is remarkably important for IIDS purposes because it states that "[h] uman beings are at the center of concerns for sustainable development. They are entitled to a healthy and productive life in harmony with nature". Although the Rio Declaration was adopted as a cooperation framework rather than as a legally binding instrument ${ }^{262}$, such approach is "consistent with public health values and WHO's mission to promote health" ${ }^{263}$. These might be the starting vehicle to import such principle into the realm of IIDS as a general principle or as a standard of international law where health issues are at stake.

\section{CONCLUSIONS}

Once the rationales and structures of both IHL and IIL are understood, it is easy to note that there are normative and factual elements that are likely to make the right to health, play second fiddle in investor-state arbitrations. Nevertheless, the adequate protection of all parties is a desirable quality in any legal system and the asymmetrical structure of rights should not prevent an individual from being adequately protected.

Certain provisions from IIL render it hard for states to effectively safeguard their citizens' health while promoting economic stability and advocating for sustainable development $^{264}$. Given the general vagueness of the primary rule, arbitral tribunals do not merely apply the law to the facts but actually act as rule makers alongside states by embracing a "gap-filling" and "norm-generative" function ${ }^{265}$. Notwithstanding, no matter how precise applicable standards are drafted, the adjudicatory process will always involve a considerable degree of discretion ${ }^{266}$. Thus, it would be ill-advised to presume that all uncertainties in investment arbitration could be countered by detailing or defining concepts or by drafting principles in new treaties with the aim of clarifying the primary rule ${ }^{267}$.

A stronger protection of the right to health could be achieved by using some of the mechanisms already available in the current $l_{a w}^{268}$. Specifically, engaging the WHO and

\footnotetext{
259 WHO (2004) p. 21.

260 WHO (2004) pp. 15-16.

261 Report of the UN Conference on Environment and Development (1992) UNGA A/CONF.151/26

(Vol. IV).

262 SheLton (2008).

263 WHO (2014) p. 22.

264 Stiglitz and Hersh (2015) p. 2.

265 RIPINSKY and SCHILL (2011) p. 600.

266 Alvarez (2016).

267 EFILA.

268 LANG (2013) p. 811.
} 
the ICJ in investor-state arbitrations when health issues are at stake may encourage reflection from a variety of perspectives to ensure that legal issues are considered in their "crosscutting nature" from a variety of perspectives ${ }^{269}$. Likewise, the importance of highlighting the precautionary principle in IIDS may work as a desired balancing mechanism among all international actors by reassessing their performance while noting third parties' interests. The latter would automatically engage all international actors with their responsibility to prevent harm and preserve health as a desirable end ${ }^{270}$.

Though the proposed mechanisms are indirect approaches to obtain health protection, it may be worth embarking on them before tackling more intricate solutions that will take longer to implement and are unlikely to reach the impact that is required to better protect public interest.

\section{CITED BIBLIOGRAPHY}

Action on Smoking and Health (2016): “Standardised tobacco packaging”, ASH Briefing. http://ash.org.uk/files/documents/ASH_877.pdf. Accessed: 27 August 2016.

Alkire, Sabina (2010): "Human development: Definitions, critiques, and related concepts", UNDP Research Paper, 2010/01. http://hdr.undp.org/sites/default/files/hdrp_ 2010_01.pdf. Accessed: 29 August 2016.

Alvarez, José (2016): "Critiques of the Investment Regime", United Nations Audiovisual Library of International Law. http://legal.un.org/avl/ls/Alvarez_IEL.html. Accessed: 7 July 2016.

Anderson, Sarah Denny and Cavanagh, John (1996): The Top 200: The Rise of Global Corporate Power (Washington DC, Institute for Policy Studies).

Bettcher, Douglas, Taylor A. L., de Chazournes, L. B., Leary, V. and Okun, H. S. (2000): "International Law and Health, Two Approaches: The World Health Organization's Tobacco Initiative and International Drug Controls", Proceedings of the Annual Meeting (American Society of International Law), vol. 94: pp. 193-196.

Bilchitz, David (2016): "The Necessity for a Business and Human Rights Treaty" Business and Human Rights Journal, vol. 1, No 2: pp. 203-227.

Bjorklund, Andrea (2013): "Practical and legal avenues to make the substantive rules and disciplines of international investment agreements converge" in ECHANDI, Roberto and SAUvé, Pierre (eds.), Prospects in International Investment Law and Policy (Cambridge, CUP) pp. 175-199.

Blake, Daniel (2013): “Thinking Ahead: Government Time Horizons and the Legalization of International Investment Agreements", International Organization, vol. 67: pp. 797-827.

Bush, Ashley, Holsinger, James and Prybil Lawrence (2016): "Employing the Precautionary Principle to Evaluate the Use of E-Cigarettes", Frontiers in public health, vol. 4: pp. 1-6.

269 LANG (2013) p. 807.

270 Schettler and Raffensperger (2004) p. 66. 
Cortés N. (2016): “The TPP as a Template to Liberalize Investments: Normative Glory or Chaos?”, Kluwer Arbitration Blog. http://kluwerarbitrationblog.com/ 2016/06/18/ tpp-template-liberalize-investments-normative-glory-chaos/. Accessed: 27 August 2016.

Crawford, James (2002): "ILC's Articles on Responsibility of States for Internationally Wrongful Acts: A Retrospect”, The American Journal of International Law, vol. 96, No 4: pp. 874-890.

Dennis, William and Chamberlain, Joseph (1932): "The doctrine of rebus sic stantibus", Proceedings of the American Society of International Law at Its Annual Meeting (19211969) vol. 26 (American Society of International Law): pp. 53-68.

Desierto, Diane (2015): Public policy in international economic law: the ICESCR in trade, finance, and investment (New York, OUP).

Diepeveen, Rosalien, Levashova Yulia and Lambooy Tineke (2014): “Bridging The Gap Between International Investment Law and The Environment', 4th And 5th November, The Hague, The Netherlands", Utrecht Journal of International and European Law, vol. 30, No 78: pp. 145-160.

Dolzer, Rudolf and Schreuer, Christoph (2012): Principles of International Investment Law (Oxford, OUP, $2^{\text {nd }}$ edn).

Dumberry, Patrick (2016): “The Importation of 'Better' Fair and Equitable Treatment Standard Protection Through MFN Clauses: An analysis of NAFTA Article 1103”, Transnational Dispute Management. https://papers.ssrn.com/sol3/papers.cfm? abstract_ $\mathrm{id}=3126512$. Accessed 7 August 2018.

Dumberry, Patrick and Dumas-Aubin, Gabrielle (2014): "How to Impose Human Rights Obligations on Corporations Under Investment Treaties?”, Yearbook on International Investment Law and Policy (2011-2012), vol. 4: pp. 569-600.

Eberhardt, Pia and Olivet, Cecilia (2012): Profiting from Injustice: How law firms, arbitrators and financiers are fuelling an investment arbitration boom (Amsterdam, CEO and the Transnational Institute).

European Federation for Investment Law and Arbitration [EFILA]. TTIP Consultation Submission http://efila.org/wp-content/uploads/2014/07/EFILA_TTIP_final_submission. pdf. Accessed: 28 August 2016.

Ferraz, Octavio Luiz Motta (2011): "Harming the Poor Through Social Rights Litigation: Lessons from Brazil”, Texas Law Review, vol. 89, No 7: pp. 1643-1668.

FietTA, Stephen (2005): "Most Favoured Nation Treatment and Dispute Resolution Under Bilateral Investment Treaties: A Turning Point?", International Arbitration Law Review, vol. 8: pp. 131-146.

Goldstein, Bernard (2001): “The precautionary principle also applies to public health actions”, American Journal of Public Health, vol. 91, No 9: pp. 1358-1361.

Gostin, L. O., Friedman, E. A., Buse, K., Waris, A., Mulumba, M., Joel, M., Dare, L., Dhai A. and Sridhar D. (2013): “Towards A Framework Convention On Global Health”, Bulletin of the World Health Organization, vol. 91: pp. 790-793.

Hepburn, Jarrod (2016): "In Dissent, Gary Born Rejects Use of 'Margin Of Appreciation' Doctrine in BIT Cases, and Sees Two Breaches By Uruguay of Philip Morris's BIT Rights", Investment Arbitration Reporter. https://www.iareporter.com/articles/in-dissent- 
gary-born-rejects-use-of-margin-of-appreciation-doctrine-in-bit-cases-and-sees-two -breaches-by-uruguay-of-philip-morriss-bit-rights/. Accessed: 30 August 2016.

International Investment Arbitration + Public Policy (2011): "Chemtura v Canada

(NAFTA Chapter 11)”, IIAP. http://www.iiapp.org/case/chemtura-v-canada/. Accessed: 27 August 2016.

ICJ. https://www.icj-cij.org/en/advisory-jurisdiction. Accessed 28 August 2018.

JАСОВ, M (2010): "International Investment Agreements and Human Rights", Research

Paper Series on Human Rights, Corporate Responsibility and Sustainable Development 03/2010, INEF. http://www.humanrights-business.org/files/international_investment_ agreements_and_human_rights.pdf. Accessed: 28 August 2016.

John, Peter (2011): Making Policy Work (Oxfordshire, Taylor \& Francis).

Jordan, Andrew and O'RiORDAN, Timothy (2004): “The precautionary principle: a legal and policy history", in Martuzzi, Marco and Tickner, Joel (eds.), The Precautionary Principle: Protecting Public Health, the Environment and the Future of our Children (Rome, WHO) pp. 31-48.

LanG, Andrew (2013): "The Role of the International Court of Justice in a Context of Fragmentation”, The International and Comparative Law Quarterly, vol. 62(4): pp. 777-812.

ManN, Howard et al. (2005): "IISD Model International Agreement on Investment for Sustainable Development”, IISD. https://www.iisd.org/pdf/2005/investment_model_ int_agreement.pdf. Accessed: 28 August 2016.

ManN, Howard (2005): "The final decision in Methanex v. United States: some new wine in some new bottles”, IISD. http://www.iisd.org/sites/default/files/public cations/commentary_methanex.pdf. Accessed: 28 August 2016.

ManN, Howard (2008): "International Investment Agreements, Business, and Human Rights: Key Issues and Opportunities”, IISD. https://www.iisd.org/pdf/ 2008/iia_business_human_rights.pdf. Accessed: 28 August 2016.

Martuzzi, Marco and Tickner, Joel (2004): “The Precautionary Principle: Protecting Public Health, the Environment and the Future of our Children”, in Martuzzi, Marco and Tickner, Joel (eds.), The Precautionary Principle: Protecting Public Health, the Environment and the Future of our Children (Rome, WHO) pp. 7-14.

Mills, Alex (2011): "Antinomies of Public and Private at the Foundations of International Investment Law and Arbitration", Journal of International Economic Law, vol. 14, No 2: pp. 469-503.

Montgomery, Jonathan (1992): "Recognizing a Right to Health", in Beddard R. and Hill D. M. (eds.), Economic, Social and Cultural Rights: Progress and Achievement (London, Macmillan) pp. 184-203.

OECD (2004): “'Indirect Expropriation' and the 'Right to Regulate' in International Investment Law”. OECD Working Papers on International Investment 2004/04. https:// www.oecd.org/daf/inv/investment-policy/WP-2004_4.pdf. Accessed 27 August 2016.

OECD (2011): "Guidelines for Multinational Enterprises". http://www.oecd.org/daf/inv/ mne/oecdguidelinesformultinationalenterprises.htm. Accessed: 27 August 2016.

Paparinskis, Martins (2013a): "Investment Treaty Arbitration and the (New) Law of State Responsibility", European Journal of International Law, vol. 24, No 2: pp. 617-647. 
PaparinsKis, Martins (2013b): The International Minimum Standard and Fair and Equitable Treatment (Oxford, OUP).

Paparinskis, Martins (2014): "Come Together or Do It My Way: No Systemic Preference", Proceedings of the Annual Meeting (American Society of International Law), vol. 108: pp. 246-249.

Pearce, Neil (2004): "Public health and the precautionary principle", in MartuzZi, Marco and Tickner Joel (eds.), The Precautionary Principle: Protecting Public Health, the Environment and the Future of our Children (Rome, WHO) pp. 49-62.

Peterson, Luke Eric (2016a): "The Philip Morris V. Uruguay Award on the Merits: Part One of our Three Part Analysis, Focusing on The Expropriation Claim", Investment Arbitration Reporter. https:/www.iareporter.com/articles/the-philip-morris-v-uruguay-aw ard-on-the-merits-part-one-of-our-three-part-analysis-focusing-on-the-expropriationclaim. Accessed: 30 August 2016.

Peterson, Luke Eric (2016b): “The Philip Morris V. Uruguay Award on the Merits: Part Two of our Three Part Analysis, Focusing on the FET And Umbrella Clause Claims", Investment Arbitration Reporter. https:/www.iareporter.com/articles/the-philip-morrisv-uruguay-award-on-the-merits-part-two-of-our-three-part-analysis-focusing-on-thefet-and-umbrella-clause-claims/. Accessed: 30 August 2016.

Pieterse, Marius (2008): "Health, Social Movements, and Rights-based Litigation in South Africa", Journal of Law and Society, vol. 35, No 3: pp. 364-388.

Pogge, Thomas (2008): World Poverty and Human Rights (Cambridge, Polity Press, $2^{\text {nd }}$ edn.). Redfern, Alan and Hunter, Martin (2009): International Arbitration (Oxford, OUP, $5^{\text {th }}$ edn.).

Ripinsky Sergey and Schill, Stephan (2011): The Multilateralization of International Investment Law, European Journal of International Law, vol. 22, No 2: pp. 598-602.

Robeyns, Ingrid (2006): "The capability approach in practice", Journal of Political Philosophy, vol. 14, No 3: pp. 351-376.

Ruger, Jennifer Prah (2008): "Normative Foundations of Global Health Law", Georgetown Law Journal, vol. 96: pp. 423-443.

RugGIE, John. UN document A/CN.9/662. https://documents-dds-ny.un.org/ doc/UNDOC/GEN/V08/543/30/PDF/V0854330.pdf?OpenElement. Accessed: 17 July 2016.

Schettler, Ted and Raffensperger, Carolyn (2004): "Why is a precautionary approach needed?", in Martuzzi, Marco and Tickner, Joel (eds), The Precautionary Principle: Protecting Public Health, the Environment and the Future of our Children (Rome, WHO) pp. 63-83.

SCHILL, Stephan (2009): The Multilateralization of International Investment Law (Cambridge, CUP).

Shelton, Dinah (2002): "Protecting human rights in a globalized world", Boston College International and Comparative Law Review, vol. 25 No 2: pp. 273-322.

Shelton, Dinah (2008): "Stockholm Declaration (1972) and Rio Declaration (1992)", Max Planck Encyclopedia of Public International Law, 14 p.

Silberhorn, Thomas (2015): “Germany's Experience in Supporting and Implementing Human Rights-Based Approaches to Health, plus Challenges and Successes in Demonstrating Impact on Health Outcomes", Health and Human Rights Journal, vol. 17, No 2: pp. 21-29. 
Skovgaard, Poulsen, Bonnitcha, Jonathan and Yackee, Jason (2013): "Analytical Framework for Assessing Costs and Benefits of Investment Protection Treaties". https:// www.gov.uk/government/uploads/system/uploads/attachment_data/file/260503/bis13-1285-analytical-framework-for-assessment-costs-and-benefits-of-investment-protection .pdf. Accessed: 27 August 2016.

STEVEns, Margaret (2013): "ICSID at the crossroads: some thoughts and recommendations for improving the dispute settlement system”, in ECHANdi Roberto and SAUvé Pierre (eds), Prospects in International Investment Law and Policy (UK, CUP) pp. 243-265.

Stiglitz, Joseph and Hersh, Adam. 'The Trans-Pacific Free-Trade Charade' (2015): "Project Syndicate". http://www.alicedewolff.ca/wp-content/uploads/2015/10/NIC-Handout-session-2.pdf. Accessed: 30 August 2016.

TAYLOR, Allyn (2002): "Global governance, international health law and WHO: looking towards the future", Bulletin of the World Health Organization, vol. 80, No 12: pp. 975-980.

VADI, Valentina (2009): “Trade Mark Protection, Public Health and International Investment Law: Strains and Paradoxes”, The European Journal of International Law, vol. 20: pp. 773-803.

WALDRON, Jeremy (2012): The rule of law and the measure of property (New York, CUP).

Weiler and Investment Treaty Counsel (2010): "Philip Morris vs. Uruguay an Analysis of Tobacco Control Measures in the Context of International Investment Law", Paper commissioned by Physicians for a Smoke Free Canada, 36 p.

WHO (2004): "Dealing with uncertainty -how can the precautionary principle help protect the future of our children?", in Martuzzi, Marco and Tickner, Joel (eds.), The Precautionary Principle: Protecting Public Health, the Environment and the Future of our Children (Rome, WHO) pp. 15-30.

WHO (2016): "World Health Statistics: Monitoring health for the SDGs". http://www. who.int/gho/publications/world_health_statistics/2016/en/. Accessed: 30 August 2016.

Widdows, Heather (2015): "Global Health Justice and the Right to Health", Health Care Anal, No. 23: pp. 391-400.

Wu, Chuan-feng (2010): "Raising the right to health concerns within the framework of international intellectual property law", Asian Journal of WTO and International Health Law and Policy, vol. 5: pp. 141-189.

Yamin, Alicia (1996): "Defining Questions: Situating Issues of Power in the Formulation of a Right to Health under International Law" Human Rights Quarterly, vol. 18: pp. 398-438.

Zhan, J. (2013): "Investment Policies For Sustainable Development", in Echandi, Roberto and SAUvé, Pierre (eds.), Prospects in International Investment Law and Policy (UK, CUP), pp. 13-29.

\section{CITED STATUTES}

Agreement between the Government of Australia and the Government of Hong Kong for the Promotion and Protection of Investments (entered into force 15 October 1993) ATS 199330. 
Arab Charter on Human Rights (2004).

Constitution of the World Health Organization (1946).

Convention on Psychotropic Substances (1971).

Convention on the Rights of the Child (1989).

European Social Charter (1996).

Framework Convention on Tobacco Control (2003).

German Model Treaty (2008).

ILC Articles on Responsibility of States for Internationally Wrongful Acts (2001).

ilC Commentaries on Draft Articles on Most-Favoured-Nation Clause. International LaW Commission A/CC.4/SER.A/1978/Add.1(Part2) (1978).

International Covenant on Economic, Social and Cultural Rights (1966).

MaAstricht Treaty on European Union (1992).

Report of the United Nations Conference on Environment and Development (1992) UNGA A/CONF.151/26 (Vol. IV).

REs. 65/22 OF THE UNCITRAL: "Arbitration Rules as revised in 2010" UNGA Res. 65/22 (2011).

Rio Declaration on Environment and Development (1992).

Single Convention on Narcotic Drugs (1961).

Statute of the International Court of Justice (1945).

Sustainable Development Goals (SDGs), WHO.

Trans-Pacific Partnership Agreement (TPP) (adopted 4 February 2016).

United Nations Convention against Illicit Traffic in Narcotic Drugs and Psychotropic Substances (1988).

Universal Declaration of Human Rights (1948).

US Model Bilateral Investment Treaty (2012).

Vienna Convention on the LaW of Treaties (1969).

\section{CITED JURISPRUDENCE}

Chemtura Corporation v. CANAdA (2010): UNCITRAL award, 2 August 2010.

Metalclad Corporation V. The United Mexican States (2000): ICSID Case No ARB(AF)/97/1, 30 August 2000.

Methanex Corporation v. United States of America (2005): UNCITRAL Final Award, 3 August 2005.

MTD EQUity SDN BHD. AND MTD ChILE SA v. ChILE (2007): ICSID Case No ARB/01/07, Decision on Annulment, 21 March 2007.

Parkerings- Compagniet v. Lithuania (2007): ICSID Case No ARB/05/8, Award, 11 September 2007.

Philip Morris Brands Sarl, Philip Morris Products S.A. and Abal Hermanos S.A. v. OrIental REPUblic of URUGUAY (2016): ICSID Case No ARB/10/7, 8 July 2016. 